\title{
Observational rock mass damage model associated to caving advance of Chuquicamata Underground Mine
}

\author{
HE Constanzo CODELCO, Chile \\ PC Guerra Derk Engineering and Geology, Chile \\ GA Barindelli CODELCO, Chile
}

\begin{abstract}
The Chuquicamata Underground Mine (ChUM) plans to reach a production regime of 140,000 tons per day (tpd). The seven-year ramp-up established to achieve this represents a major challenge. The Chuquicamata Underground Mine uses the block caving method, characterized by a dynamic caving front that constantly modifies the stress condition of the rock mass which reflects damage to the production sector's drifts. It also uses a combination of preconditioning by hydraulic fracturing and confined blasting, referred to as intensive preconditioning (Catalan et al. 2017). By identifying the variables that impact the behavior of the rock mass damage caused by the mining advance, it is possible to obtain an observational model for use in evaluations that minimize bias because the variables impacting the damage are clearly identified and the model's application in the mine (undercut and production level drifts) requires lowcomplexity training. Use of the observational model to assess rock mass damage associated with the caving progression in the Chuquicamata Underground Mine permits evaluation of its behavior prior to mining activity and the application of different exploitation strategies, using unbiased information. This is related to the physical parameters that govern the caving behavior and permits the subsequent calibration of numerical models.
\end{abstract}

\section{Introduction}

The Chuquicamata Underground Mine is a massive underground mine designed to recover approximately 1,760 million tons of ore, with an average grade of $0.712 \%$ of copper, 512 ppm of molybdenum and 492 ppm of arsenic, prolonging the mine's life by approximately 39 years and reaching production in regime of 140,000 tons of ore, with a ramp-up of seven years.

The exploitation method selected for ChUM is block caving in its macroblock (MB) variant, with three levels of exploitation located at levels 1841, 1409 and 1193. From a geotechnical point of view, another important feature is the vertical distance between the bottom of the open pit and the underground mine (approximately 280 meters, 565 meters and 784 meters for the first, second and third levels, respectively) (Figure 1A).

In addition, intensive preconditioning is used to manage caveability, cave growth geometry and fragmentation. These processes involve treating or modifying the characteristics of the rock mass using fluid injection or fully confined blasting (Flores \& Catalan 2019).

The crosscut and production drifts take place before the cave front and are affected by the "abutment stress" it generates (Figure 1B). The general structure of the operational exploitation sequence is defined as follows:

- Horizontal development (drifts) by levels

- Construction

- Preconditioning 
- Draw-bell blasting from the production level, ahead of the cave front

- Undercutting

- Ore extraction, after the draw-bell commissioning.

The comparative advantage of this block caving variant is that, in a macroblock, all the unitary development and construction operations are carried out before the block base is cut. The undercut level (UCL) is located 18 meters above the production level (measured from the production level floor to the UCL floor).
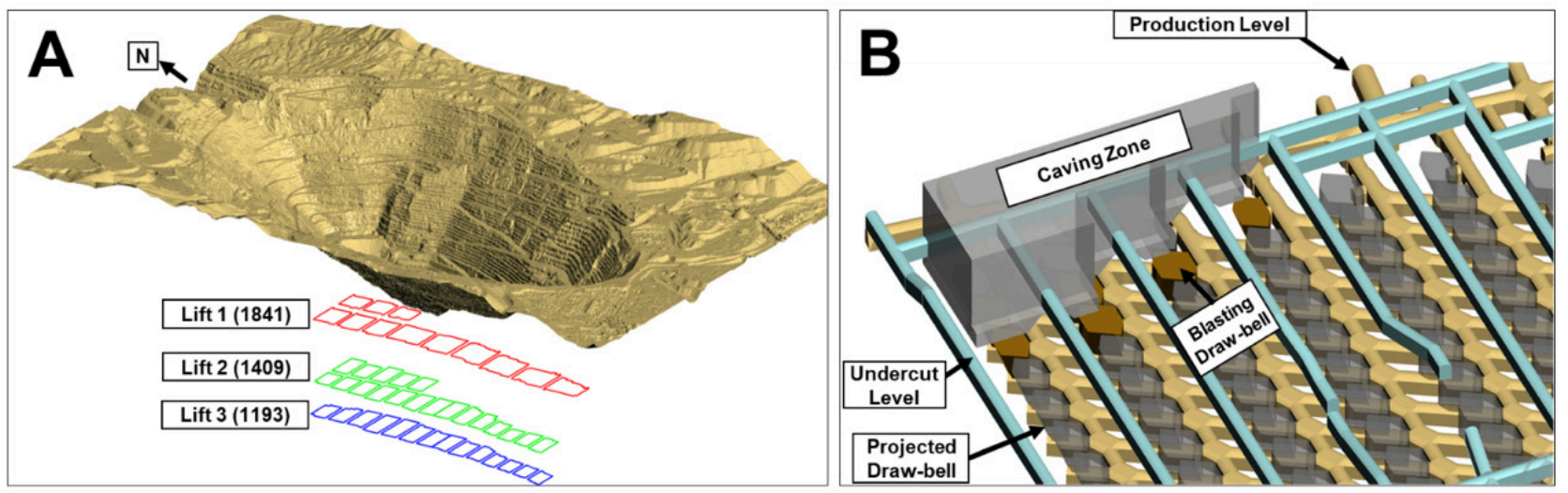

Figure 1 Exploitation levels of Chuquicamata Underground Mine: (A) scheme of cave advance and (B) blasting of draw-bells

The construction of the draw-bell begins with the drilling of a blind hole with a diameter of 1.5 meters in the middle of the draw-bell crosscut, followed by draw-bell blasting in one phase in which the blasting is carried out in independent events. It should be noted that the draw-bell is not so far fully open since there is a 4-meter safety pillar between the open draw-bell and the UCL. To complete the draw-bell opening, radial boreholes are made for cutting the base of the block and the safety pillar.

The block caving exploitation method is based on making a cut at the base of the mineralized block to ensure that no remaining pillars serve as support points. In this way, the lower base of the block acts as an abutment beam and, as a result of external forces, principally gravity, the block progressively collapses and the resulting mineralized fragments are transported according to the sector's materials handling.

The basal cut made to the block is the so-called cave front which, due to its advance, is dynamic and constantly alters the condition of the rock mass. This is reflected in damage caused at the UCL and at the lower levels. The production level is the area most affected, due to the loadings generated by the cave front.

The damage caused by the cave front will depend on some of the characteristics of each mine sector: stress field, lithology, structures, physical-mechanical properties of the rock, existing ground support, orientation, shape and size of the cave front, size and shape of the pillars, etc. An important factor to consider is the cave front downtime, mainly over long periods.

\section{Methodology}

\subsection{Rock mass damage evaluation}

The rock mass damage starts to manifest itself as from the start of the developments, principally when mining exploitation of the sector begins. This is due to changes in the tension condition produced by the advance of the cave front and the opening of the draw-bells. 
According to the existing literature, (Constanzo et al. 1998; Constanzo \& Parraguez 2001), there are ways to assess the damage but they cannot be extrapolated to all rock masses because of the different characteristics of each reservoir and the exploitation method used. Nonetheless, variables that would identify the different changes in the drifts condition at the Chuquicamata Underground Mine were defined.

This main objective is to standardize the damage assessment criteria so that, from a practical standpoint, the rock mass damage can be evaluated in a certain, efficient and objective manner, without depending on the criteria of the geotechnical engineer carrying out the evaluation.

To estimate the level of damage to the rock mass and determine the variables that influence its degradation, it is necessary to consider the geotechnical variables that affect the behavior of the rock mass. This is discussed later in this paper. For this, a three-dimensional intact rock blocks arrangement is defined and delimited by discontinuities or planes of weakness. It is, therefore, of great interest to analyze all those rock mass deformation indicators that can be evaluated through observational control.

When a rock mass is undergoing deformation processes, it will tend to mobilize rock blocks, especially at the periphery of the underground excavation. Obviously, the most severe deformation processes will also show evidence of failed or fractured rock resulting from the in-situ ground stress induced around the excavations. Similarly, if support elements are located in the rock mass, they are also subject to deformations, which can be ranked depending on their intensity and their effect on the support elements.

The movements of the contour blocks will increase the excavation section when these blocks fall or are removed. The water effect and the rock mass support elements must also be added to the effect of the loads induced by the stress field. Water has a degrading effect on the support elements, particularly in terms of oxidation of steel bars and meshes.

\subsection{Description of geotechnical variables}

In the study described by Constanzo et al. (1998), the damage in the drift of the El Teniente mine was evaluated by identifying and quantifying variables observed on the ground, permitting the development of an observational model of damage, which was applied in the different production sectors of the caving mine. The following variables were defined for a qualitative evaluation of the rock mass damage associated with caving mine exploitation: over-excavation, block formation, groundwater and ground support.

In this study, each variable was ordered according to the degree of importance observed on the ground, assigning it a weight, which was estimated based on the authors' experience. Such weights have been used in previous studies of caving mines (Constanzo \& Parraguez 2001). However, they were updated for conditions at the Chuquicamata Underground Mine, with a predominance of the block formation and ground support variables, which were each given a weight of 0.35 . They were followed by the least influential variables: over-break and groundwater, each with a weight of 0.15 .

\subsubsection{Over-break}

Over-break corresponds to an unwanted increase in the drift dimensions, which can be generated during the development or by mining activity in the vicinity. It usually manifests itself initially as mobilization of rock chips or preformed blocks delimited by discontinuities. Over-break has a weight of 0.15 .

\section{a. Over-break during development}

The development of the drift is the first activity carried out during the preparation. It alters and weakens the rock mass. It is necessary to reduce this anomaly in order to preserve the proposed mine layout. The main principle of fortification is, therefore, used. It consists in the self-support of the work, based on the characteristics of the rock mass as a support element.

b. Over-break due to mining activity 
Mining using the caving method causes important changes in the rock mass, leading the tensional state to change as the cave front advances and affecting the nearby drifts. This, in turn, increases the induced stress (abutment stress) in the immediate vicinity of the cave front while, behind the cave front, there is a relaxed area. This effect can manifest itself in ways that include damage due to deformation, seismicity and falling wedges behind the front. The resulting variations in the rock mass can be evaluated considering the degree of over-break produced. For over-break parameterization, only the measurement is considered.

For over-break quantification, the different parameters considered are based on the rock mass's deterioration or degradation and are shown in Table 1 and Figure 2.

\section{Table 1 Ratings adjusted to ChUM according to the over-break geotechnical parameter}

\begin{tabular}{|c|c|c|c|}
\hline A & Half barrel & $\begin{array}{c}\text { Over-break (weighting } 0.15 \text { ) } \\
\text { Half barrel reflecting absence of alteration in the rock, } \\
\text { assuming that the original rock mass remains intact. }\end{array}$ & 100 \\
\hline B & Over-break<1 m & The rock mass has been little altered by mining. & 80 \\
\hline C & 1 m<over-break<1.5 m & The rock mass has been moderately altered by mining. & 65 \\
\hline D & Over-break $>1.5 \mathrm{~m}$ & The rock mass has been strongly altered by mining. & 30 \\
\hline
\end{tabular}
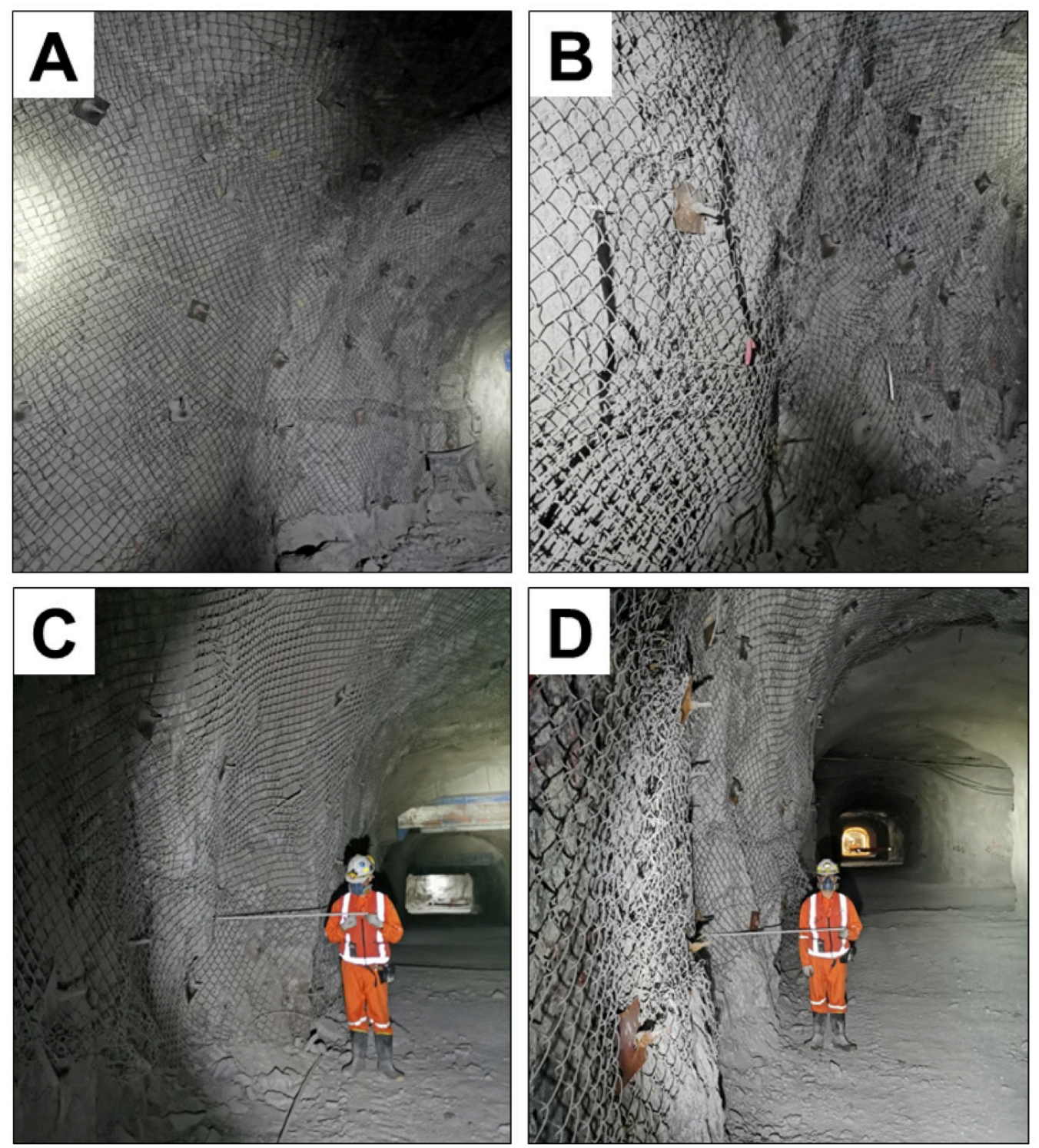

Figure 2 Classification of over-break underground: half barrel (A), over-break $<1 \mathrm{~m} \mathrm{(B),} 1 \mathrm{~m}<$ over-break $<1.5 \mathrm{~m}$ (C) and over-break $>1.5 \mathrm{~m}$ (D) 


\subsubsection{Block formation}

The rock mass is a three-dimensional arrangement of rock blocks delimited by discontinuities. These blocks can move in the contours of the excavation due to mining activity deformations, particularly in the case of block caving where there is an increased stress field induced by the cave front. According to the definition of rock mass (Hoek 2001; Palmström \& Strömme 1996), the rock blocks are part of the structure of the rock mass. It is, therefore, necessary to evaluate the rock mass and the state of the excavation's contour blocks. In general, rock mass mechanical behavior will depend on the following factors:

a. Properties of the rock mass structures that define the rock blocks;

b. Block set interaction.

For the parameterization of the effect of mining on the rock mass, the different deformation manifestations indicated by the blocks are considered (Table 2 and Figure 3). Block formation has a weight of 0.35 .
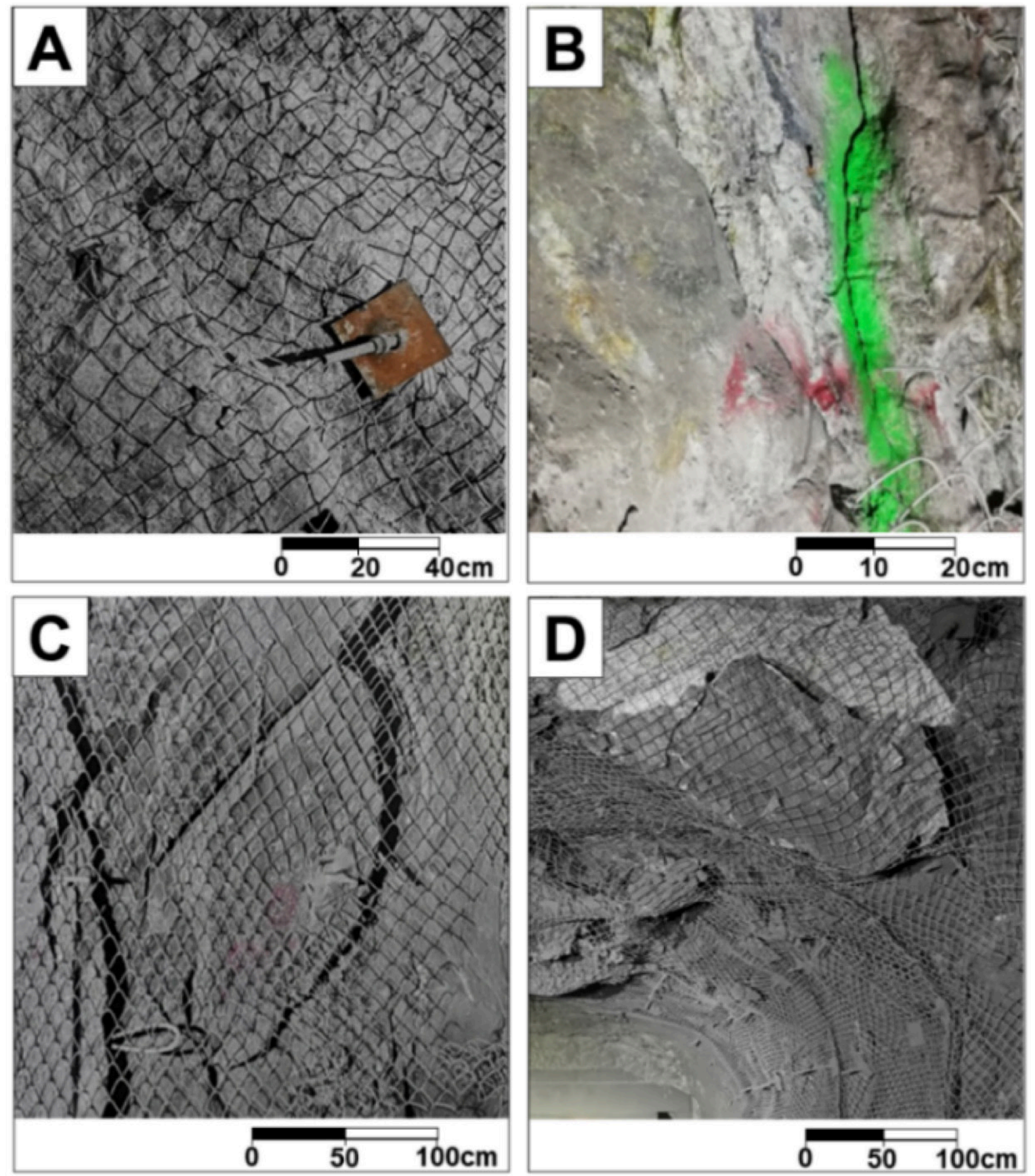

Figure 3 Classification of block formation underground: not activated (A), activated (B), blocky ground (C) and detachment blocky (D) 
Table 2 Ratings adjusted to ChUM according to the block formation geotechnical parameter

\begin{tabular}{|c|c|c|c|}
\hline & & Block formation (weighting 0.35 ) & Ratings \\
\hline A & Not activated & $\begin{array}{c}\text { The rock mass with or without blocks limited by closed } \\
\text { structures is observed. }\end{array}$ & 100 \\
\hline B & Activated & $\begin{array}{l}\text { The rock mass with blocks limited by activated or open } \\
\text { structures is observed, but the block remains attached to the } \\
\text { rock mass. }\end{array}$ & 70 \\
\hline C & Blocky ground & $\begin{array}{l}\text { The rock mass with blocks limited by open structures and with } \\
\text { kinematic possibilities of movement is observed. }\end{array}$ & 40 \\
\hline D & Detachment blocky & $\begin{array}{c}\text { The rock mass with blocks limited by open structures is } \\
\text { observed in addition to block detachment. }\end{array}$ & 10 \\
\hline
\end{tabular}

\subsubsection{Groundwater}

As indicated, the presence of water is a factor that implies additional loads on the rock mass, permitting the mobilization of the blocks if the hydraulic pressure is adequate. In addition, it is an agent that deteriorates the installed support elements.

Table 3 and Figure 4 show the different descriptions considered for the presence of groundwater, which help to quantify its effect on the behavior of the rock mass. Water has a weight of 0.15 .
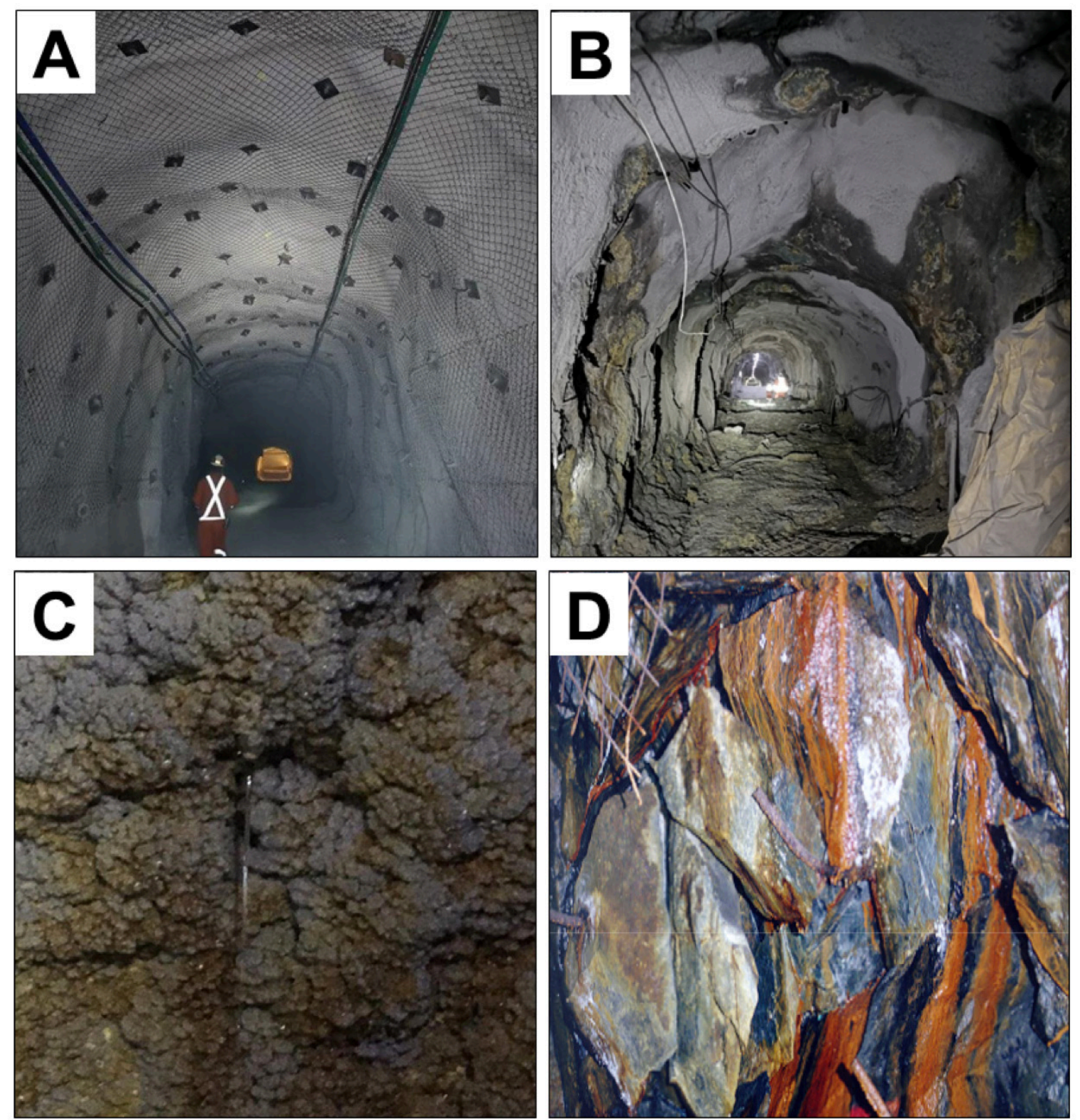

Figure 4 Classification of groundwater underground: dry (A), wet (B), dripping (C) and flowing (D) 
Table 3 Ratings adjusted to ChUM according to the groundwater geotechnical parameter

\begin{tabular}{|c|c|c|c|}
\hline & & Groundwater (weighting 0.15) & Ratings \\
\hline A & Dry & $\begin{array}{c}\text { The rock mass does not show moisture on its surface and/or associated } \\
\text { with geological structures. }\end{array}$ & 100 \\
\hline B & Wet & $\begin{array}{c}\text { The rock mass presents moisture on its surface and geological } \\
\text { structures. }\end{array}$ & 75 \\
\hline C & Dripping & $\begin{array}{l}\text { The rock mass has water runoff on its surface and structures (water } \\
\text { leaks are verified intermittently and in specific sectors of the work). }\end{array}$ & 40 \\
\hline D & Flowing & $\begin{array}{c}\text { The rock mass has water runoff on its surface and continuous filtration } \\
\text { through geological structures. }\end{array}$ & 20 \\
\hline
\end{tabular}

\subsubsection{Ground support}

The ground support aims to compensate for the imbalances that occur around the excavations due to the distribution of the in-situ ground stress. The support is affected by the rock mass damage processes and becomes loaded or, in other words, contains broken surface fragments which, in some more severe cases, can cause it to fail or leave it out of service. The support state in different locations has, therefore, been determined according to the classification shown in Table 4 and Figure 5. Ground support has a weight of 0.35 .
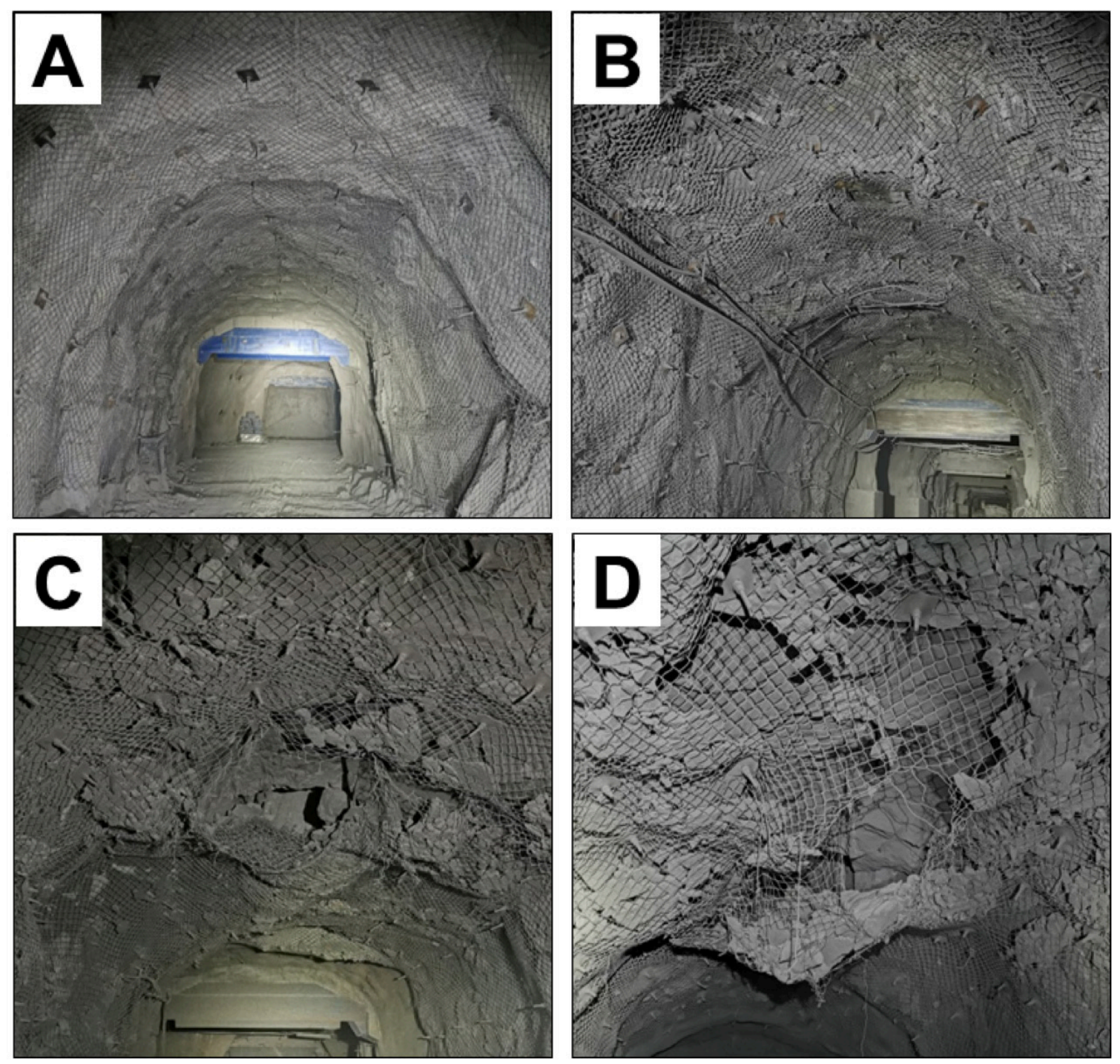

Figure 5 Classification of ground support underground: installed (A), slightly requested (B), strongly requested (C) and out of service (D) 
Table 4 Ratings adjusted to ChUM according to the ground support geotechnical parameter

\begin{tabular}{|c|c|c|c|c|}
\hline A & Installed & $\begin{array}{c}\text { Ground support (weighting 0.35) } \\
\text { The support has no relevant modifications since its installation (whalesback } \\
\text { are not observed, the fortification elements present no corrosion, the } \\
\text { rock-bolts are fully anchored in the rock, the wire meshes are attached to } \\
\text { the rock mass, the shotcrete has no cracks, the washers are attached to } \\
\text { the rock mass and without stress signs). }\end{array}$ & 100 \\
\hline B & $\begin{array}{c}\text { Slightly } \\
\text { Requested }\end{array}$ & $\begin{array}{c}\text { Loaded mesh is observed without significant deformation, the shotcrete } \\
\text { has incipient cracks and the other elements of ground support do not } \\
\text { present major changes. }\end{array}$ & 70 \\
\hline C & $\begin{array}{c}\text { Strongly } \\
\text { requested }\end{array}$ & $\begin{array}{c}\text { The mesh is loaded, containing a large quantity of rocks and yielding in } \\
\text { the form of a pocket. It is also possible to observe blocks or whalesback } \\
\text { attached to bolts, loaded washers (deformed) and open cracks in the } \\
\text { shotcrete. }\end{array}$ & 50 \\
\hline D & $\begin{array}{c}\text { Out of } \\
\text { service }\end{array}$ & $\begin{array}{c}\text { Ground support loses its support capacity (50\% of the rock-bolts' length } \\
\text { outside the rock mass, the shotcrete has cracks and whalesback, wire } \\
\text { meshes are cut or broken, strong corrosion by water through rock-bolts } \\
\text { and/or cracks). }\end{array}$ & 10 \\
\hline
\end{tabular}

\subsection{Classification criteria}

The geotechnical variables described above were weighted according to their relevance in the evaluation of the rock mass, assigning a weight of between $0 \%$ and $100 \%$ to each of them. The sum of the geotechnical variables equals 100\% (Constanzo \& Parraguez 2001).

Each of the variables was weighted considering the expert criteria of every participant in this study and the relevance of each of these aspects in the conditions of the Chuquicamata mine, particularly the presence of water. The value assigned to each variable is shown in Table 5.

\section{Table 5 Weighting adjusted to ChUM according to geotechnical parameters}

\begin{tabular}{|c|c|c|c|c|c|}
\hline $\begin{array}{c}\text { Geotechnical } \\
\text { parameter }\end{array}$ & $\begin{array}{c}\text { General } \\
\text { condition }\end{array}$ & Weighting & W & \\
\hline $\begin{array}{c}\text { Over-break (OB) } \\
\text { Ratings }\end{array}$ & $\begin{array}{c}\text { Half barrel } \\
100\end{array}$ & $\begin{array}{c}\mathrm{OB}<1 \mathrm{~m} \\
80\end{array}$ & $\begin{array}{c}1 \mathrm{~m}<\mathrm{OB}<1.5 \mathrm{~m} \\
65\end{array}$ & $\begin{array}{c}\mathrm{OB}>1.5 \mathrm{~m} \\
30\end{array}$ & $15 \%$ \\
\hline $\begin{array}{c}\text { Block formation (B) } \\
\text { Ratings }\end{array}$ & $\begin{array}{c}\text { Not activated } \\
100\end{array}$ & $\begin{array}{c}\text { Activated } \\
70\end{array}$ & $\begin{array}{c}\text { Blocky ground } \\
40\end{array}$ & $\begin{array}{c}\text { Detachment } \\
\text { blocky } \\
10\end{array}$ & $35 \%$ \\
\hline $\begin{array}{c}\text { Groundwater(W) } \\
\text { Ratings }\end{array}$ & 100 & $\begin{array}{c}\text { Wet } \\
75\end{array}$ & $\begin{array}{c}\text { Dripping } \\
40\end{array}$ & $\begin{array}{c}\text { Flowing } \\
20\end{array}$ & $15 \%$ \\
\hline $\begin{array}{c}\text { Ground support } \\
\text { (GS) }\end{array}$ & Installed & $\begin{array}{c}\text { Slightly } \\
\text { Ratings }\end{array}$ & $\begin{array}{c}\text { Strongly } \\
\text { requested } \\
50\end{array}$ & $\begin{array}{c}\text { Out of service } \\
10\end{array}$ & $35 \%$ \\
\hline
\end{tabular}

Equation 1 shows the respective weights for each geotechnical variable, which must be multiplied by each rating and added to each other to obtain a final score that is classified as shown in Table 6.

$$
\text { Score }=0.150 B+0.35 B+0.15 W+0.35 G S
$$

Where: 


$$
\begin{aligned}
& \mathrm{OB}=\text { Over-break rating obtained in ground evaluation } \\
& \mathrm{B}=\text { Block formation rating obtained in ground evaluation } \\
& \mathrm{W}=\text { Groundwater rating obtained in ground evaluation } \\
& \mathrm{GS}=\text { Ground support rating obtained in ground evaluation }
\end{aligned}
$$

Table 6 Classification scale defined for the rock mass condition

\begin{tabular}{|c|c|c|c|}
\hline Score & $\mathbf{1 0 0 - 7 1}$ & $\mathbf{7 1 - 4 1}$ & $<\mathbf{4 1}$ \\
\hline State & $\begin{array}{c}\text { Good rock mass } \\
\text { condition }(\mathrm{A})\end{array}$ & $\begin{array}{c}\text { Regular rock mass } \\
\text { condition (B) }\end{array}$ & $\begin{array}{c}\text { Poor rock mass } \\
\text { condition (C) }\end{array}$ \\
\hline
\end{tabular}

Having a rock mass evaluation scale has the following benefits:

a. It is possible to compare the state of the rock mass in different sectors of the mine.

b. "Biases" in the rock mass evaluation are eliminated.

c. The rock mass damage evaluation is independent of the person performing it.

\section{$3 \quad$ Results}

\subsection{Application of the observational rock mass damage model}

Rock mass evaluation is a tool that permits appraisal of mining layout designs in a practical way, once mining exploitation has begun. In this way, the designs implemented can be validated or improved. Some of its applications are described below.

\subsubsection{Mining effects}

The advance of the cave front causes considerable changes in the state of the rock mass due to the accommodation of stress fields that occur in the operations sector, significantly affecting the level of production. At the Chuquicamata mine, there was no damage associated with the cave front effect at the beginning of caving in June 2019 (Figure 6A). In September 2019, as the cave front advanced, there was also no damage associated with the cave front activity (Figure 6B). There were, however, some drifts in a regular rock mass condition (blue), associated with the confined blasting of the intensive preconditioning (GRMD - CODELCO 2019b).

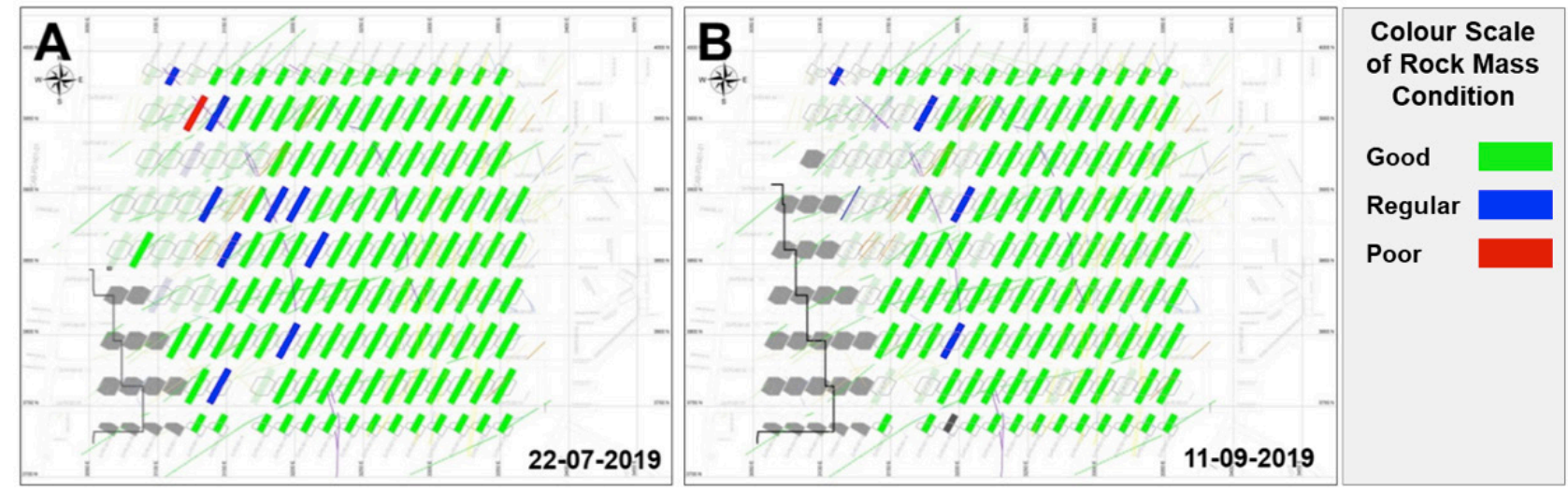

Figure 6 Rock mass damage evolution

\subsubsection{Ground support repair and reinforcement}

The observational model is an impartial and quick tool that indicates the mine sectors in need of repair and reinforcement in order to continue with the mine operations, such as the cave front advance, drilling and ore extraction. At the Chuquicamata Underground Mine (Figure 7A), periodic assessments of the rock 
mass state are carried out using the methodology described here and the sectors in need of reinforcement are identified: those in state $C$ (poor rock mass condition - red) and state B (regular rock mass condition - blue) as seen in June 2019 (damage associated with the confined blasting of intensive preconditioning). After the repair was performed, the observation model was again applied to assess the state of the rock mass (Figure 7B) and it showed the improvements in the reinforced sector (GRMD - CODELCO 2019a).

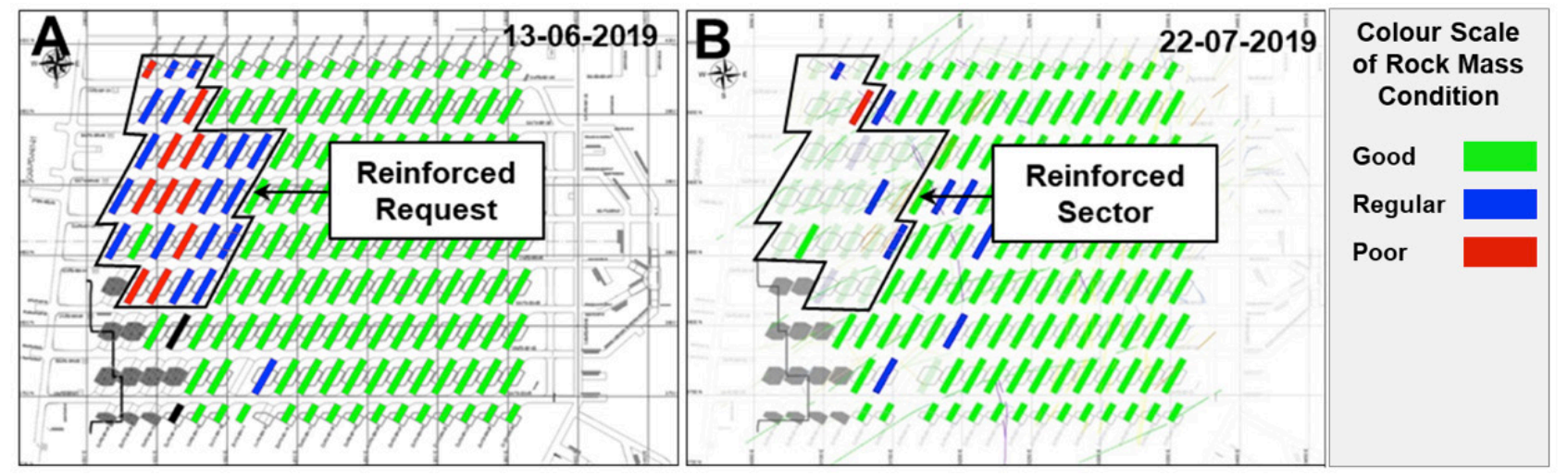

Figure 7 Rock mass damage evaluation (A) and reinforced drifts (B)

\subsubsection{Corroboration of rock mass status results with seismic instrumentation}

To corroborate the results of the evaluation of the state of the rock mass, they were compared with information obtained through seismic instrumentation. The latter corresponds to seismic tomography, a technique to identify differences between the physical properties of a body (interior, sections or volumes) that measures seismic waves to show the different propagation speeds through a continuous medium.

In solid bodies, the waves that can be propagated are the dilatational component (stress wave), which is referred to as the P wave (primary), and the shear component wave, referred to as the $S$ wave (secondary). Seismic tomography analyses of the P waves permit a better appreciation of the wave's arrival time to the sensor since they are recorded first.

The spatial arrangement of the $P$ waves is associated with the elastic-plastic constants of the rock mass (including Young's modulus and Poisson's ratio), permitting identification of the irregular zones generated by structures, fractures, change of lithological units, stress concentrations, etc. In this way, it is possible to determine the changes suffered by the $P$ waves inside the rock mass and associate it with irregularities inside it (Table 7).

Table 7 P wave velocity ranges and rock mass classification

\begin{tabular}{|c|c|}
\hline Average speed compression wave $\mathbf{V} \mathbf{p}(\mathbf{m} / \mathbf{s})$ & Rock mass condition \\
\hline $5,200-6,400$ & Very Good \\
\hline $4,000-5,200$ & Good \\
\hline $2,400-4,000$ & Regular \\
\hline Less than 2,400 & Bad \\
\hline
\end{tabular}

In Figure 8, it can be seen that the results of the rock mass evaluation of 13 June 2019 (GRMD - CODELCO 2019a) and the seismic tomography of 7 August 2019 are concordant since the acoustic measurement shows P-wave velocity values of close to $2,400 \mathrm{~m} / \mathrm{s}$ at the pillar contour. This implies bad quality rock mass in line with its classification as state $C$ according to the observational rock mass evaluation. 


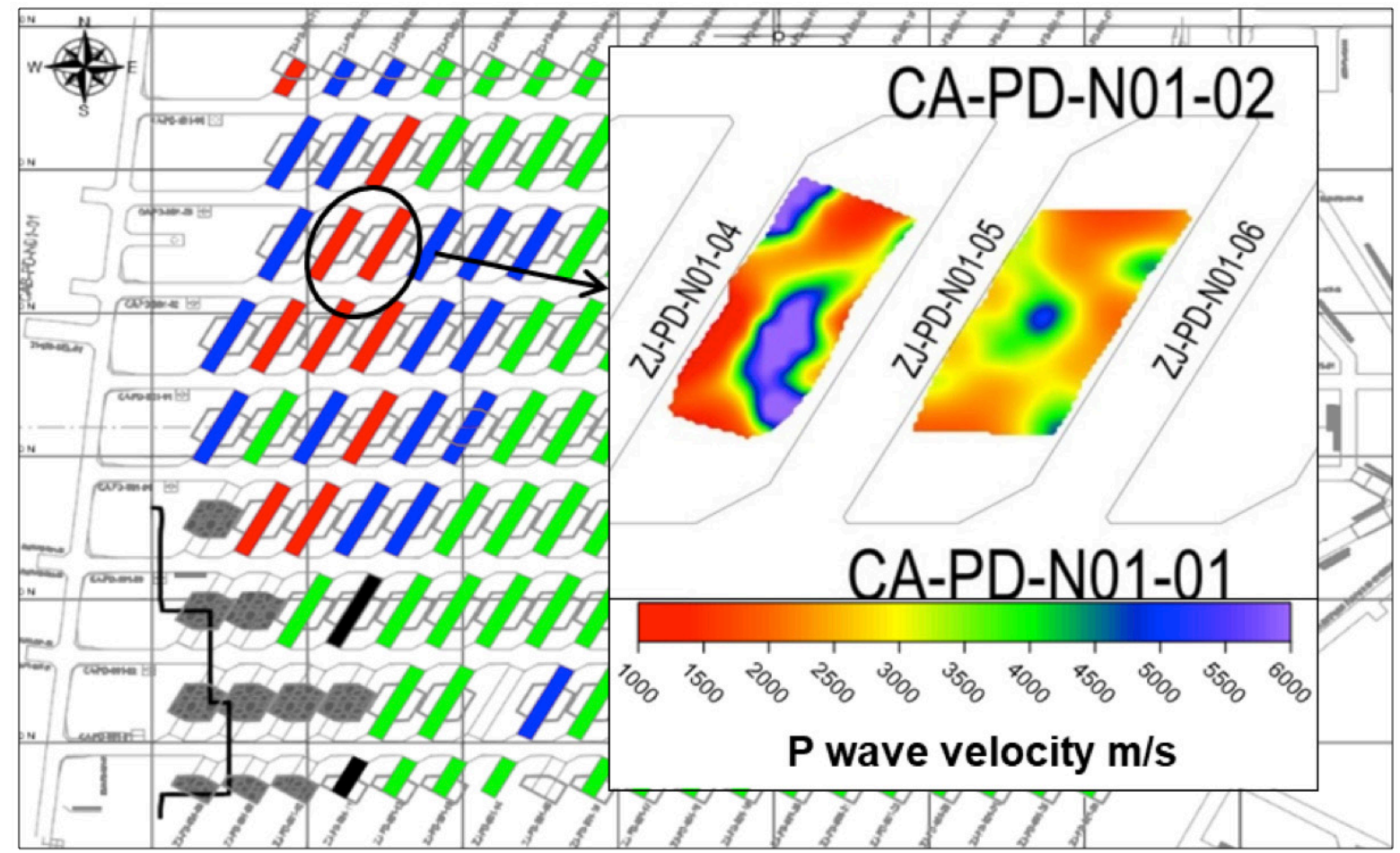

Figure 8 Evaluation of pillars between production drives 1 and 2 north and crosscut 4 and 6, macroblock N1-S1

The tomography reports a P-wave velocity variation of between 3,000 and $6,000 \mathrm{~m} / \mathrm{s}$ on the pillar contour, with a P-wave velocity average of $4,600 \mathrm{~m} / \mathrm{s}$, indicating a good quality pillar. Similarly, the rock mass observational evaluation indicates that the pillar is in state $A$.

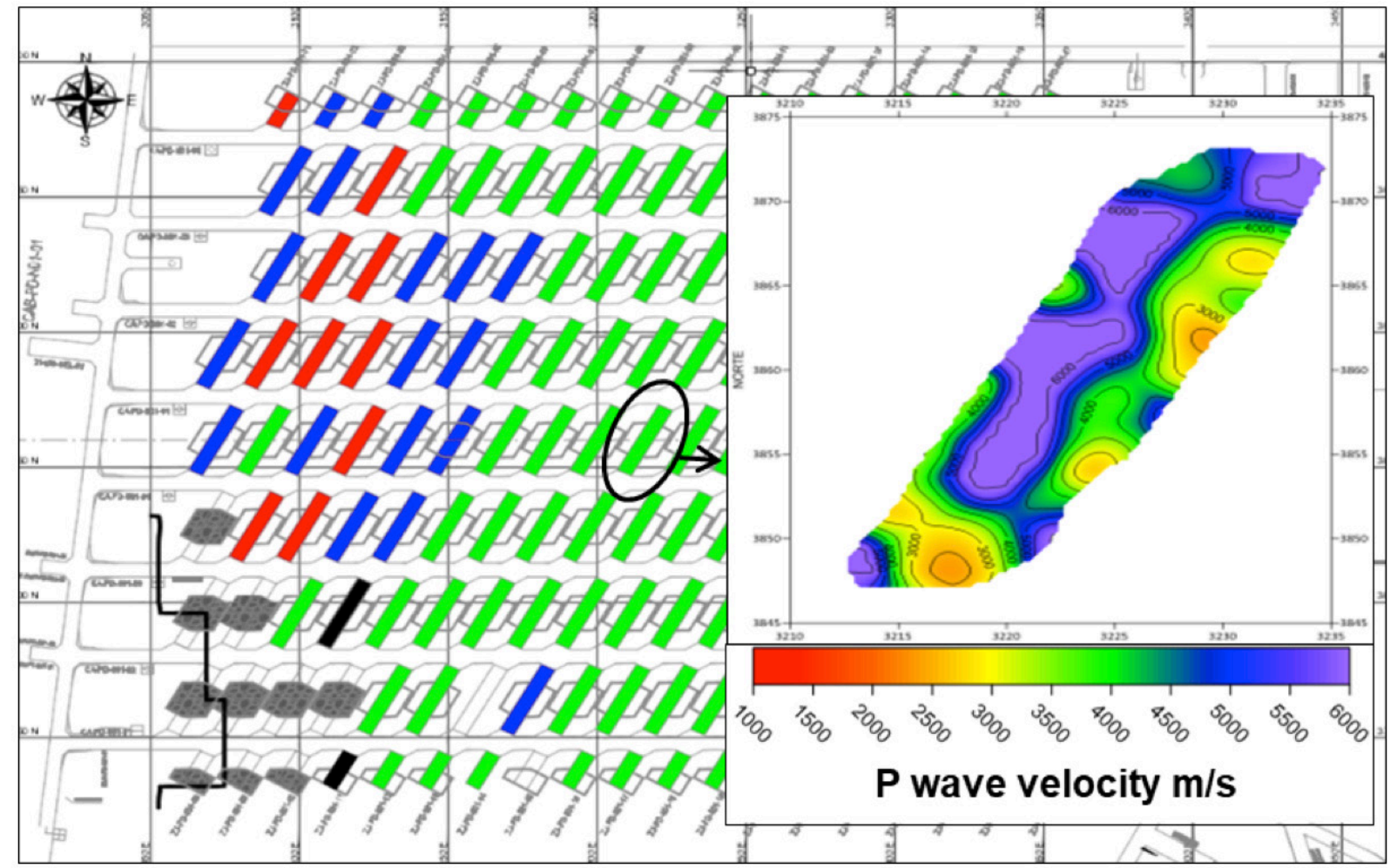

Figure 9 Evaluation of pillars between production drives 4 and 1 south and crosscut 13 and 14, macroblock N1S1 


\section{Conclusions}

The main objective of this methodology is to standardize criteria so that, from a practical standpoint, rock mass damage can be evaluated in a certain, efficient and objective way, without depending on the criteria of the geotechnical engineer performing the evaluation.

By using the observational model for evaluating damage in the drifts of the production and undercut levels, associated with the progress of mining exploitation, it is possible to determine whether the strategy considered is in line with expectations.

The identification of sectors with more or less damage enables mine operations to take action to minimize sectors of instability.

This observational model was validated through seismic tomography on the pillars of the production level, obtaining a clear correlation between wave speeds and the level of damage observed in the drift walls.

\section{References}

Catalan, A, Onederra, I, \& Chitombo, G 2017, 'Evaluation of intensive preconditioning in block and panel caving-part II, quantifying the effect on seismicity and draw rates', Transactions of the Institutions of Mining and Metallurgy, Section A: Mining Technology, vol. 126, no. 4, pp. 221-239.

Constanzo, HB \& Parraguez, RR 2001, 'Utilización de un modelo de daño en el macizo rocoso como herramienta de apoyo en los diseños Geomecánico de la mina El Teniente', Simposium de Ingeniería en Minas. $2^{\circ}$ Edición SIMIN II, in Spanish.

Constanzo, HB, Guerra, LV, Moreno, LT \& Osses, AM 1998, 'Metodología Práctica para Evaluación cualitativa del Daño al Macizo Rocoso, Fortificación y Puntos de Extracción según Actividad Minera Caso: Área Invariante de Tte-Sub6', Informe Técnico PL-I-045-98. Superintendencia General Planificación MINCO, División El Teniente- CODELCO Chile, in Spanish.

Flores, G, \& Catalan, A 2019, 'A transition from a large open pit into a novel "macroblock variant" block caving geometry at Chuquicamata mine, CODELCO-Chile', Journal of Rock Mechanics and Geotechnical Engineering, vol. 11, no. 3, pp. 549-561.

GRMD - CODELCO 2019a, 'Plano De Estado Macizo Rocoso Nivel Hundimiento Y Producción', División Chuquicamata, Gerencia de Recursos Mineros y Desarrollo, CODELCO, Nota técnica, GRMD-SPM-081-2019, [September 2019], in Spanish.

GRMD - CODELCO 2019b, 'Plano De Estado Macizo Rocoso Nivel Hundimiento Y Producción N1 y S1', División Chuquicamata, Gerencia de Recursos Mineros y Desarrollo, Nota técnica, CODELCO, GRMD-SPM-119-2019, [19 December 2019], in Spanish.

Hoek, E 2001, Rock mass properties for underground mines, Underground Mining Methods: Engineering Fundamentals and International Case Studies, Littleton, Colorado.

Palmström, A, \& Strömme, B 1996, 'The Rock Mass index (RMĐ applied in rock mechanics and rock engineering', Journal of Rock Mechanics and Tunnelling Technology, vol. 11, no. 2, pp. 1-40. 